\title{
Localization of gene and protein expressions of tumor necrosis factor- $\alpha$ and tumor necrosis factor receptor types I and II in the bovine corpus luteum during the estrous cycle ${ }^{1}$
}

\author{
R. Sakumoto, ${ }^{* 2}$ M. Vermehren, $\dagger$ R. A. Kenngott, $\dagger$ K. Okuda, $\ddagger$ and F. Sinowatz $\dagger$ \\ *Reproductive Biology Research Unit, National Institute of Agrobiological Sciences, Ibaraki 305-0901, Japan; \\ $\dagger$ Institute of Veterinary Anatomy, Histology and Embryology, Ludwig-Maximilians University, Munich 80539, \\ Germany; and ‡Laboratory of Reproductive Endocrinology, Okayama University, Okayama 700-8530, Japan
}

\begin{abstract}
One of the many roles of tumor necrosis factor (TNF)- $\alpha$ is to control mammalian corpus luteum (CL) PG synthesis and apoptotic cell death. Here, the cellular localization of TNF- $\alpha$ and its type I (TNF-RI) and type II (TNF-RII) receptors in bovine luteal tissue were analyzed using in situ hybridization, immunohistochemistry, and quantitative realtime PCR. Transcripts for TNF- $\alpha$ were expressed in bovine CL throughout the estrous cycle, but were significantly more abundant $(P<0.01)$ at the regressed luteal stage than at the other stages. Localization of $T N F-\alpha$ transcripts and protein were observed in large and small bovine luteal cells, as well as in immune cells.
\end{abstract}

Moreover, transcripts for TNF-RI and TNF-RII were expressed in bovine CL throughout the estrous cycle. The abundance of TNF-RII transcripts was greater $(P$ $<0.01)$ at the regressed luteal stage than at the other stages, whereas TNF-RI transcript abundance did not significantly change. Expression of TNF-RI and TNF$R I I$ transcripts and proteins were observed in both the large and small luteal cells, and the proteins were also expressed in the immune cells and vascular endothelial cells. These results suggest that TNF- $\alpha$ sources include immune cells, as well as large and small luteal cells, and that TNF-RI and TNF-RII are present in the luteal cells of the bovine CL.

Key words: cow, corpus luteum, receptor, tumor necrosis factor- $\alpha$

(C) 2011 American Society of Animal Science. All rights reserved.

J. Anim. Sci. 2011. 89:3040-3047 doi:10.2527/jas.2010-3479

\section{INTRODUCTION}

The corpus luteum (CL) is a transient ovarian organ established by cells of the follicle after ovulation. The primary product of the CL, progesterone, is required for the establishment and maintenance of pregnancy (Niswender et al., 2000). The bovine CL is composed of both steroidogenic luteal cells and nonsteroidogenic cells (i.e., vascular endothelial cells, fibroblasts, and immune cells such as lymphocytes and macrophages; O'Shea et al., 1989).

\footnotetext{
${ }^{1}$ This research was supported by a Grant-in-Aid for Scientific Research (No. 21780259) from the Japanese Society for the Promotion of Science. Ryosuke Sakumoto was supported by a Research Fellowship Program of the Alexander von Humboldt Foundation (Germany). The authors thank Dieter Schams of the Technical University of Munich for the TNF antibody and the staff of the Institute of Veterinary Anatomy, Ludwig-Maximilians University, Munich, for their skilled technical assistance.

${ }^{2}$ Corresponding author: sakumoto@affrc.go.jp

Received September 1, 2010.

Accepted April 27, 2011.
}

Tumor necrosis factor (TNF)- $\alpha$, a nonglycosylated protein with a molecular weight of $17 \mathrm{kDa}$, was first described as a tumoricidal factor produced by activated macrophages (Carswell et al., 1975). This protein has 2 immunologically distinct receptors, type I (TNF-RI; $55 \mathrm{kDa}$ ) and type II (TNF-RII; $75 \mathrm{kDa}$; Tartaglia and Goeddel, 1992) that have different intracellular signaling pathways (Ihnatko and Kubeš, 2007). It has been demonstrated that TNF stimulates PG production and induces apoptotic cell death of cultured bovine luteal cells (Sakumoto et al., 2000; Taniguchi et al., 2002). In addition, TNF- $\alpha$ has the capacity to both shorten and prolong the CL lifespan, which depends on its concentration in the cow (Skarzynski et al., 2003, 2009), suggesting that $\mathrm{TNF}-\alpha$ has a key role in regulating bovine CL function. It has previously been shown that mRNA for $T N F-\alpha$ and $T N F-R I$ are expressed in the bovine CL (Sakumoto et al., 2000); however, the source and target cells of TNF- $\alpha$ in the bovine CL are not clear. The objectives of the present study were to determine which cell types express TNF- $\alpha$, TNF-RI, and TNF-RII by measuring the distribution of their mRNA and proteins in the bovine CL from different stages of the estrous 
cycle, analyzed using real-time PCR, in situ hybridization, and immunohistochemistry.

\section{MATERIALS AND METHODS}

\section{Collection of the Bovine Corpus Luteum}

Ovaries containing CL from German Fleckvieh cows were collected at a local abattoir within 10 to $30 \mathrm{~min}$ of exsanguination in accorance with protocols approved by the local institutional animal care and use committee. The luteal stage was classified as early ( 2 to $4 \mathrm{~d}$ after ovulation), mid ( 8 to $11 \mathrm{~d}$ ), late (14 to $16 \mathrm{~d}$ ), or regressed (19 to $21 \mathrm{~d}$ ) by macroscopic observation of the ovary ( $\mathrm{n}=5 /$ stage) as described previously (Okuda et al., 1988; Arosh et al., 2002). For gene expression studies, the CL were immediately separated from the ovaries then cut into small pieces $\left(<0.8 \mathrm{~cm}^{3}\right)$. These CL pieces were submerged in RNAlater (Qiagen $\mathrm{GmbH}$, Hilden, Germany) and stored at $-80^{\circ} \mathrm{C}$ until use. For histological studies, the CL tissues $(\mathrm{n}=3 /$ stage) were cut into small pieces $\left(<1.5 \mathrm{~cm}^{3}\right)$ and fixed in $3.7 \%$ paraformaldehyde in PBS for $24 \mathrm{~h}$. Thereafter, samples were dehydrated in a graded series of ethanol, cleared in xylene, and embedded in paraffin.

\section{Real-Time PCR}

Total RNA isolation and subsequent reverse transcription and real-time PCR steps were carried out as described previously (Sakumoto et al., 2006). The primers encoding the bovine sequences were designed and synthesized as listed in Table 1.

Gene expression was measured by real-time PCR using an iQ5 Real-time PCR analyzing system (Bio-Rad Laboratories Inc., Hercules, CA) and iQ SYBR Green Supermix (170-8880, Bio-Rad Laboratories) starting with $500 \mathrm{ng}$ of reverse-transcribed total RNA. The expression of $18 \mathrm{~S}$ rRNA ( $R \boldsymbol{N 1 8 S 1}$ ) was used as an internal control, and the primer sequences for $R N 18 S 1$ are shown in Table 1. The primer length (20 bp) and GC contents of each primer (50 to $60 \%$ ) were selected to avoid primer dimer formation, and PCR was performed under the following conditions: (first step) $95^{\circ} \mathrm{C}$ for 75 $\mathrm{s} ; 45$ cycles of $95^{\circ} \mathrm{C}$ for $15 \mathrm{~s}, 60^{\circ} \mathrm{C}$ for $30 \mathrm{~s}$ and (second step) $95^{\circ} \mathrm{C}$ for $60 \mathrm{~s}$; then 70 cycles of $60^{\circ} \mathrm{C}$ for $10 \mathrm{~s}$.
The reaction was then held at $25^{\circ} \mathrm{C}$. Each $\mathrm{PCR}$ was followed by obtaining melting curves to ensure single product amplification. The cycle number required for achieving a definite SYBR Green fluorescence signal (crossing point) was calculated by iCycler iQ software (Bio-Rad Laboratories). As standard curves, serial dilutions of appropriate cDNA were used for gene quantification. The obtained data were normalized on the basis of RN18S1 mRNA content. Previous studies from our laboratory and by other investigators have validated the use of $R N 18 S 1$ as a normalizing standard for assessing gene expression at different luteal developmental stages in cows (Townson et al., 2002; Sakumoto et al., 2010). Use of the iQ5 Real-time PCR analyzing system at increased temperatures resulted in reliable and sensitive quantification of the reverse-transcription PCR products with high linearity (Pearson correlation coefficient $r>0.98)$. To exclude the presence of any contaminating genomic DNA, all experiments included controls lacking the reverse-transcription enzyme. As a negative template control, water was used in place of RNA for the reverse-transcription reaction to exclude the presence of any contamination from buffers and tubes. The PCR products for $T N F-\alpha, T N F-R I$, and TNF-RII were sequenced and confirmed to be $100 \%$ homologous with their bovine sequences (GENterprise, Mainz, Germany).

\section{In Situ Hybridization}

Messenger RNA localization of TNF- $\alpha$, TNF-RI, and TNF-RII were achieved using in situ hybridization as described previously (Sinowatz et al., 2006). Briefly, 6 sections $(5 \mu \mathrm{m} /$ each) were prepared from CL of mid-luteal stage $(\mathrm{n}=3)$ and were mounted on slides (SuperFrost Ultra Plus; Menzel-Gläser, Braunschweig, Germany) precoated with aminopropyltriethoxysilane (APES). All solutions for in situ hybridization were prepared using diethylpyrocarbonate-treated water and glassware sterilized at $200^{\circ} \mathrm{C}$. All steps before and during hybridization were conducted under ribonucleasefree conditions. Sections were deparaffinized with xylene $(3 \times 5 \mathrm{~min})$, immersed in isopropanol $(3 \times 5 \mathrm{~min})$, and then allowed to air dry. Dried sections were submerged in $2 \times$ saline sodium citrate prewarmed $\left(80^{\circ} \mathrm{C}\right)$ in a water bath for $10 \mathrm{~min}$ and were then left at room

Table 1. Primers used in real-time $\mathrm{PCR}^{1}$

\begin{tabular}{|c|c|c|c|c|}
\hline Gene & Primer & Sequence $\left(5^{\prime}-3^{\prime}\right)$ & $\begin{array}{l}\text { GenBank } \\
\text { accession No. }\end{array}$ & $\begin{array}{l}\text { Product } \\
\text { size, bp }\end{array}$ \\
\hline$T N F-\alpha$ & $\begin{array}{l}\text { Forward } \\
\text { Reverse }\end{array}$ & $\begin{array}{l}\text { CATCCTGTCTGCCATCAAGA } \\
\text { GGCGATGATCCCAAAGTAGA }\end{array}$ & BC134755 & 193 \\
\hline$T N F-R I$ & $\begin{array}{l}\text { Forward } \\
\text { Reverse }\end{array}$ & $\begin{array}{l}\text { GTGGAGATTTCGCCTTGTGT } \\
\text { TTGGCGCCTTTAAGAAAGAA }\end{array}$ & BC113278 & 200 \\
\hline$T N F-R I I$ & $\begin{array}{l}\text { Forward } \\
\text { Reverse }\end{array}$ & $\begin{array}{l}\text { CAGGCTGTGTTTACCCCCTA } \\
\text { TGTCCAAGGTCATGTTGCAT }\end{array}$ & BC105222 & 142 \\
\hline
\end{tabular}

${ }^{1} \mathrm{TNF}=$ tumor necrosis factor; TNF-R $=\mathrm{TNF}$ receptor; $R N 18 S 1=18 \mathrm{~S}$ rRNA. 
temperature (RT) for 20 min. Slides were then washed in distilled water $(2 \times 5 \mathrm{~min}), 50 \mathrm{mM}$ Tris-buffered saline (TBS, pH 7.4; $2 \times 5 \mathrm{~min}$ ), and incubated for 20 min with $0.05 \%$ proteinase E (VWR, Ismaning, Germany) in TBS at RT. After washing in TBS $(2 \times 5$ min) and distilled water, sections were dehydrated in an ascending graded series of isopropanol and air-dried. Hybridization was carried out by overlaying the dried sections with $40 \mu \mathrm{L}$ of the corresponding biotinylated oligonucleotide probe $(100 \mathrm{pmol} / \mu \mathrm{L})$, diluted 1:20 in in situ hybridization buffer (DAKO Cytomation Inc., Carpinteria, CA), and incubation under a coverslip in a humidified chamber at $38^{\circ} \mathrm{C}$ overnight. Afterward, slides were washed in $2 \times$ saline sodium citrate $(2 \times 15 \mathrm{~min})$, prewarmed to $38^{\circ} \mathrm{C}$, and TBS $(3 \times 5 \mathrm{~min})$. Detection of transcripts was performed using a streptavidin-biotin peroxidase complex (ABC) kit (K0377, DAKO Cytomation Inc.). The sections were then reacted with $\mathrm{ABC}$ reagent for 30 min at RT. The bound complex was made visible by reaction with 3,3 '-diaminobenzidine tetrahydrochloride (DAB) in solution buffer (K3465, DAKO Cytomation Inc.) for 3 to 8 min at RT. For negative controls, parallel sections were hybridized either with the sense oligonucleotide probe or with buffer alone. The sequences of the antisense oligonucleotides were as follows: TNF- $\alpha$ : 5'- CATCCTGTCTGCCATCAAGA-3'; TNF-RI: 5'-GTGGAGATTTCGCCTTGTGT-3'; and TNF-RII: 5'-CAGGCTGTGTTTACCCCCTA-3'.

\section{Immunohistochemistry}

Antigen localization of TNF- $\alpha$, TNF-RI, and TNFRII was achieved using the streptavidin-biotin-horseradish peroxidase complex technique (Kenngott and Sinowatz, 2008). Six sections $(5 \mu \mathrm{m})$ were prepared from CL of each stage $(\mathrm{n}=3)$ and were mounted on slides coated with APES. To expose antigenic sites, dewaxed sections were heated 4 times to $95^{\circ} \mathrm{C}$ in a $600-\mathrm{W}$ microwave oven in citrate buffer $(\mathrm{pH} \mathrm{6.1)}$ for $5 \mathrm{~min}$ and allowed to cool for $20 \mathrm{~min}$ at RT. Endogenous peroxidase activity was then eliminated by incubation with $0.3 \% \mathrm{H}_{2} \mathrm{O}_{2}$ in $70 \%$ methanol for 10 min at RT. Nonspecific protein binding was eliminated by incubation with Protein Block Serum-Free (X0909, DAKO Cytomation Inc.) for $10 \mathrm{~min}$ at RT. Sections were then treated with the following antibodies: TNF- $\alpha$ (kindly donated by Dieter Schams of the Technical University of Munich, Germany; dilution 1:4,000), TNF-RI (ab19139, Abcam plc., Cambridge, UK; dilution 1:50,000), and TNF-RII (ab15563, Abcam; dilution 1:5,000). To determine the localization of the immune cells and steroidogenic luteal cells, the antibodies to CD8 (MCA877G, AbD Serotec, Kidlington, UK; dilution 1:500) and cytochrome P450 side chain cleavage enzyme (CYP450, 12-1244; American Research Products Inc., Belmont, MA; dilution 1:200) were also used. Incubation was performed for $18 \mathrm{~h}$ at $4^{\circ} \mathrm{C}$ in a humidified chamber. After being washed with $0.1 \mathrm{M}$ PBS $(3 \times 3 \mathrm{~min})$, the sections were incubated with biotinylated swine anti-rabbit IgG
(E0431, DAKO Cytomation Inc.; dilution 1:300) for 30 min at RT. The sections were then reacted with $\mathrm{ABC}$ kit for 30 min at RT. The bound complex was made visible by reaction with DAB in solution buffer for 3 to 8 min at RT. Sections were counterstained in Mayer's hematoxylin, dehydrated, and mounted with DePeX Eukitt (Riedel de Haen, Seelze, Germany). As a negative control, an antibody dilution buffer (S3022, DAKO Cytomation Inc.) was used instead of the specific first antibody.

\section{Statistical Analyses}

Experimental data for real-time PCR are presented as the mean \pm SEM. The statistical significance of differences in the abundance of mRNA expression was assessed by 1-way ANOVA with the KaleidaGraph 3.6 (Synergy Software., Reading, PA) software package. When ANOVA showed a significant effect of stage, the stages were compared by the Bonferroni posthoc multiple comparison test. A $P$-value $<0.05$ was considered statistically significant.

\section{RESULTS}

\section{Expression of TNF- $\alpha, T N F-R I$, and TNF- RII $m R N A$ in the Bovine CL}

Specific transcripts for $T N F-\alpha, T N F-R I$, and $T N F-$ $R I I$ were detected in the bovine CL throughout the estrous cycle. Transcripts of TNF and TNF-RII were more abundant $(P<0.01)$ in the regressed stage of the estrous cycle (Figures 1A and 1C), whereas the expression of TNF-RI mRNA did not change $(P>0.05)$ during the estrous cycle (Figure 1B).

\section{Localization of TNF- $\alpha, T N F-R I$, and TNF- RII Transcripts and Proteins in the Bovine CL During the Estrous Cycle}

Expression of $T N F-\alpha$ mRNA and protein were observed in the cytoplasm of bovine large and small luteal cells, as well as immune cells in the bovine CL during the estrous cycle (Figures 2A and 3). Messenger RNA for TNF-RI and TNF-RII were expressed both in the large and small luteal cells in the bovine CL (Figures $2 \mathrm{~B}$ and $2 \mathrm{C}$ ), and their proteins were also expressed in the immune cells and endothelial cells throughout the estrous cycle (Figures 4 and 5). Positive immunoreactivities of CD8 and CYP450 were observed in several cells of bovine CL, and these cells could be defined as T-cells and steroidogenic luteal cells, respectively (Figures $3 \mathrm{E}$ and $3 \mathrm{~F}$ ).

\section{DISCUSSION}

The present study shows that TNF- $\alpha$ mRNA expression in the bovine CL was more abundant at the regressed stage than at the other stages. Apoptotic cell 

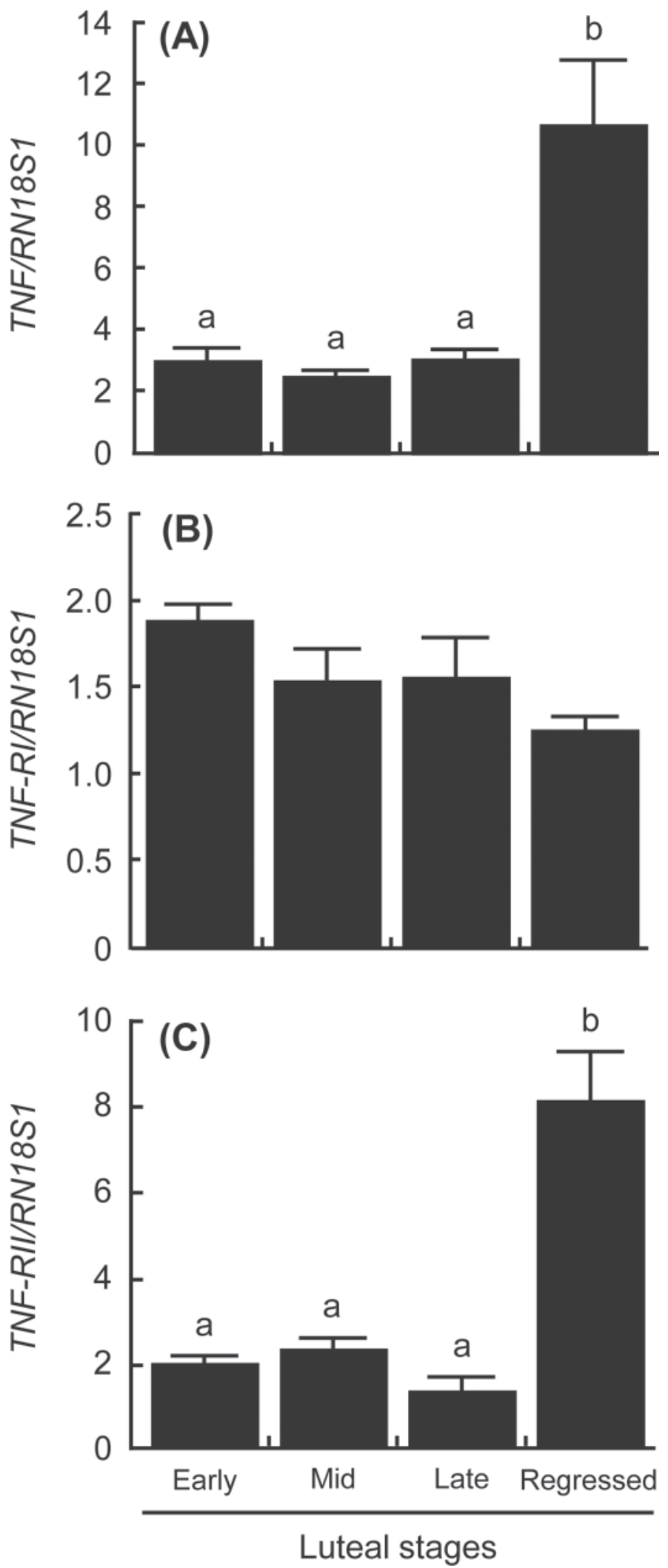

Figure 1. Changes in relative amounts of tumor necrosis factor $(T N F)-\alpha$, TNF receptor $(T N F-R) I$, and TNF-RII mRNA expression in the bovine corpus luteum (CL) throughout the estrous cycle. Data are the means \pm SEM for 5 cows per stage and are expressed as relative ratios of TNF, TNF-RI, and TNF-RII mRNA to $18 \mathrm{~S}$ rRNA (RN18S1). ${ }^{\mathrm{a}, \mathrm{b}}$ Bars without a common letter differ $(P<0.01)$. death occurs during structural luteolysis in a variety of species, including cows (Niswender et al., 2000). It is known that TNF-RI has a death domain in its intracellular signaling cascade (Ihnatko and Kubeš, 2007) and is recognized as a cell death-inducing factor (Okuda and Sakumoto, 2003). It has been demonstrated that TNF- $\alpha$ induces interferon- $\gamma-$ and Fas-mediated apoptotic cell death in bovine luteal cells by increasing caspase-3 activation (Taniguchi et al., 2002). Furthermore, TNF induces a significant increase in the expression of major histocompatibility class I glycoproteins in cultured bovine luteal cells (Benyo and Pate, 1992). It is hypothesized that these glycoproteins are recognized by cytotoxic $\mathrm{T}$ lymphocytes in order for the $\mathrm{T}$ lymphocytes to phagocytize luteal cells (Benyo and Pate, 1992). Hence, it was expected that at least TNF-RI mRNA expression would be increased in the bovine CL of late and regressed luteal stages. However, the pres-

\section{(A) TNF}

(B) TNF-RI

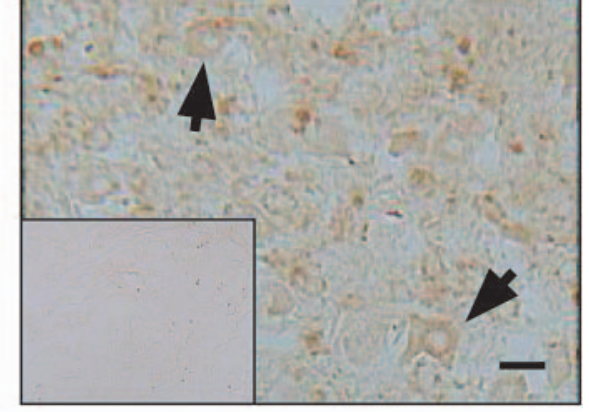

(C) TNF-RII

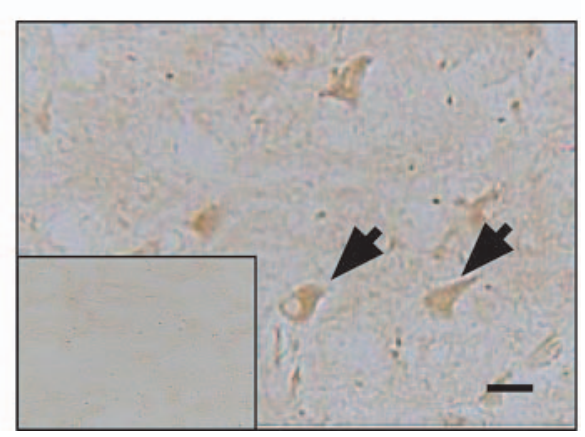

Figure 2. Distributions of A) tumor necrosis factor $(T N F)-\alpha, \mathrm{B})$ TNF receptor $(T N F-R) I$, and C) TNF-RII mRNA in the bovine corpus luteum (CL) of mid-luteal stage using nonradioactive in situ hybridization. Large cells (black arrows), small cells [white (yellow) arrows], and immune cells [gray (blue) arrows] in the bovine CL showed positive staining. Controls performed by using the sense oligonucleotide for hybridization regularly showed no signal (inset panels). Scale bars represent $25 \mu \mathrm{m}$. References to color refer to the color version available in the online PDF. 
(A) Early (TNF)

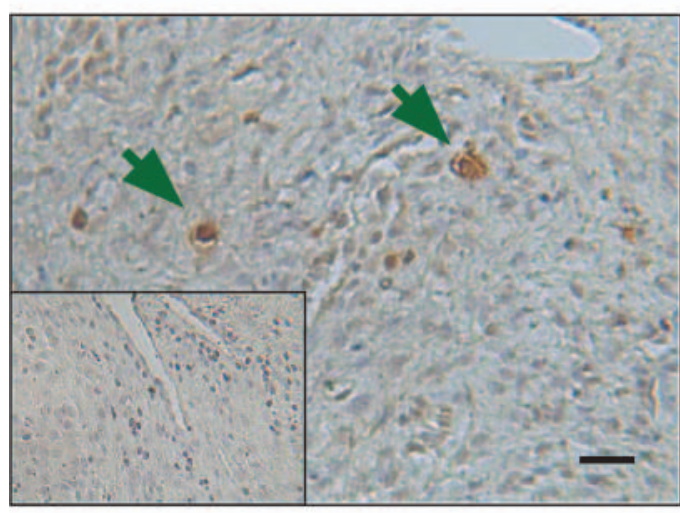

(C) Late (TNF)

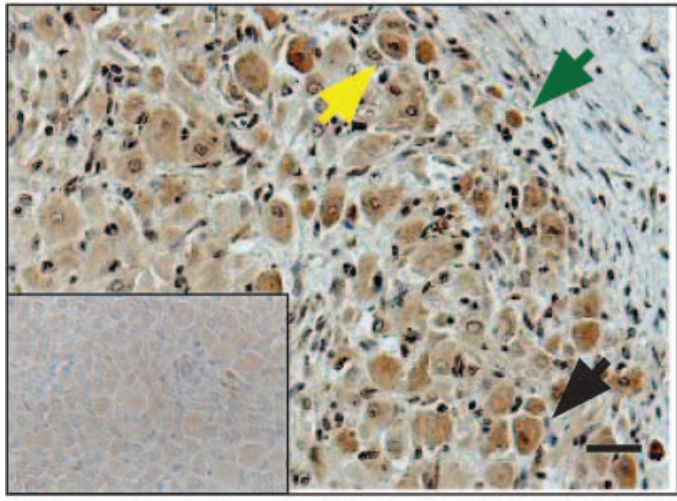

(E) Early (CD8)

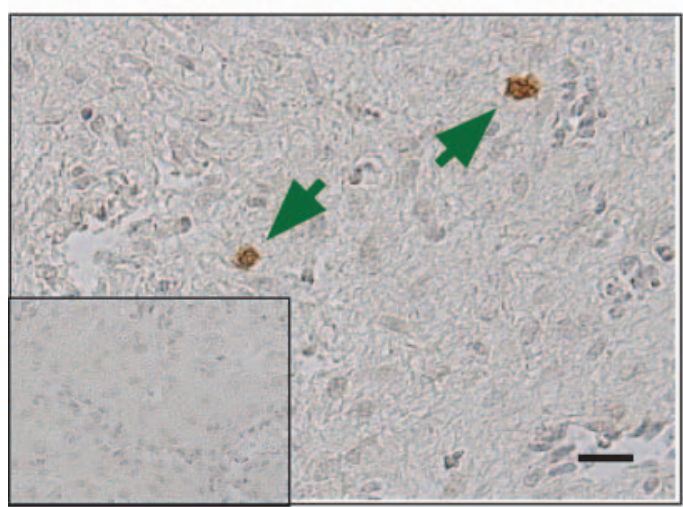

(B) Mid (TNF)

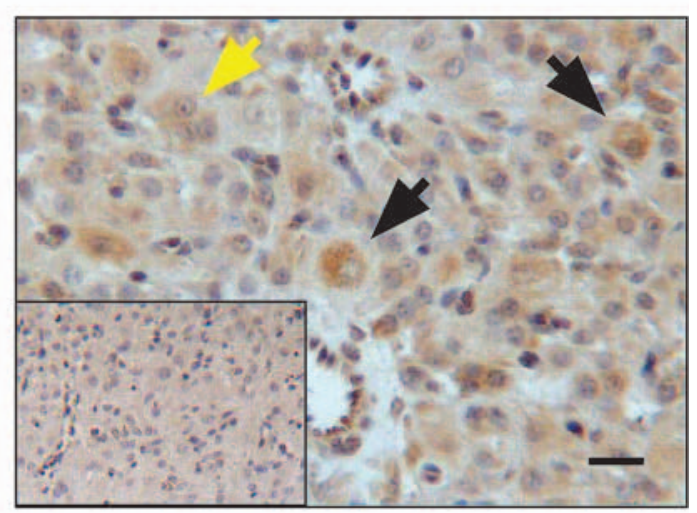

(D) Reg (TNF)

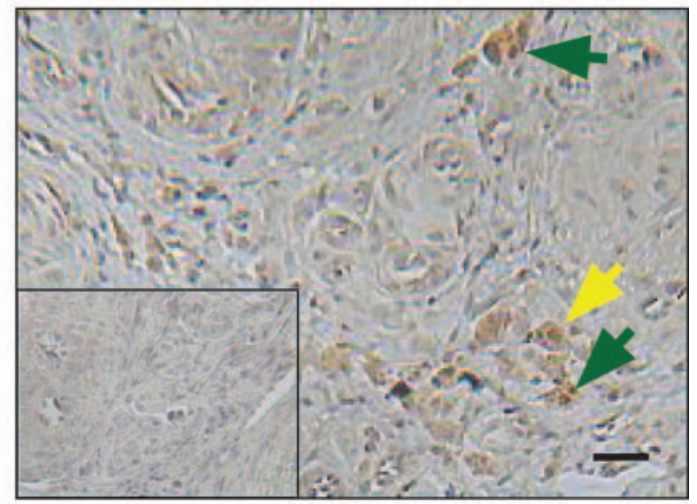

(F) Mid (CYP450)

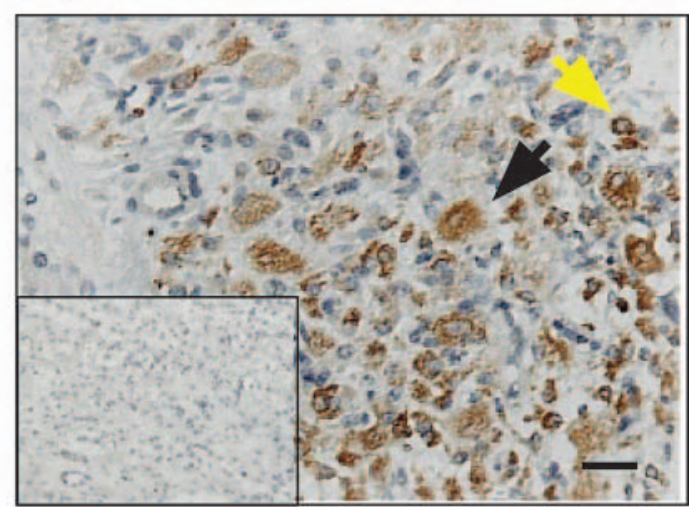

Figure 3. Representative images of immunohistochemical staining for tumor necrosis factor (TNF)- $\alpha$ [early, A; mid, B; late, C; regressed (Reg), D], CD8 (E), and cytochrome P450 side chain cleavage enzyme (CYP450; F) in the bovine corpus luteum (CL) during the estrous cycle. Large cells (black arrows), small cells [white (yellow) arrows], and immune cells [gray (blue) arrows] in the bovine CL showed positive immunoreactivity. No positive immunoreactivity was observed in negative controls (inset panels). Scale bars represent $25 \mu \mathrm{m}$. References to color refer to the color version available in the online PDF.

ent quantitative study demonstrated that the TNF-RI mRNA expression in the bovine CL did not change significantly during the estrous cycle. These data contrast with those showing TNF-RI mRNA expression being greater in the CL of developing (Sakumoto et al., 2000) and regressed stages (Korzekwa et al., 2008) than the other stages using semiquantitative analyses. An explanation for the paradoxical results is unknown. Because the concentrations of TNF- $\alpha$ in the bovine CL are greatest at the late and regressed stages (Shaw and
Britt, 1995; Penny et al., 1999; Sakumoto et al., 2000), the actions of TNF- $\alpha$ on bovine CL cells may depend on the concentration of TNF rather than the amounts of TNF-RI.

In contrast to the role of TNF-RI, the role of TNFRII in the ovary is poorly understood. The TNF-RII was found in the granulosa cells of porcine ovary (Nakayama et al., 2003) and the CL in rats (Abdo et al., 2008) and primates (Peluffo et al., 2009). The TNF-RII mRNA expression was greatest in the CL of the re- 


\section{(A) Early (TNF-RI)}

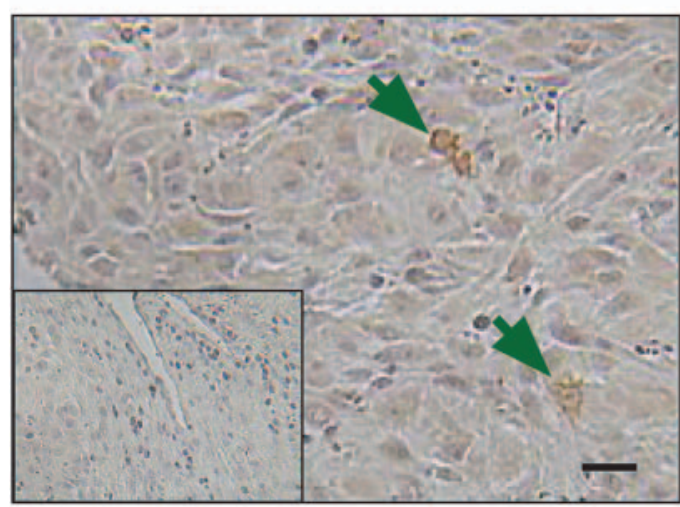

(C) Late (TNF-RI)

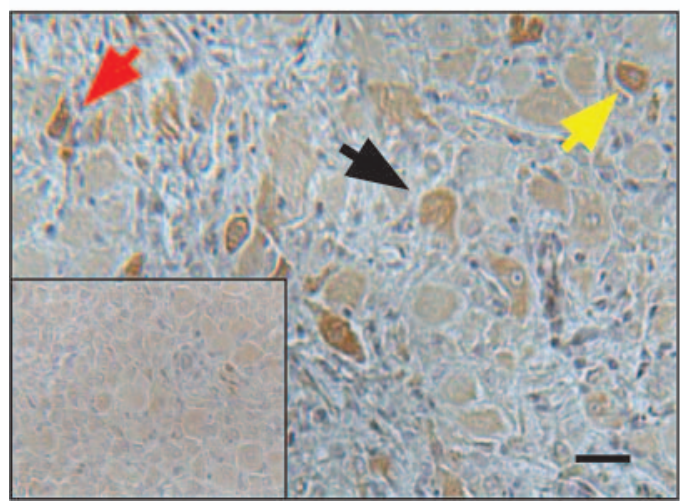

(B) Mid (TNF-RI)

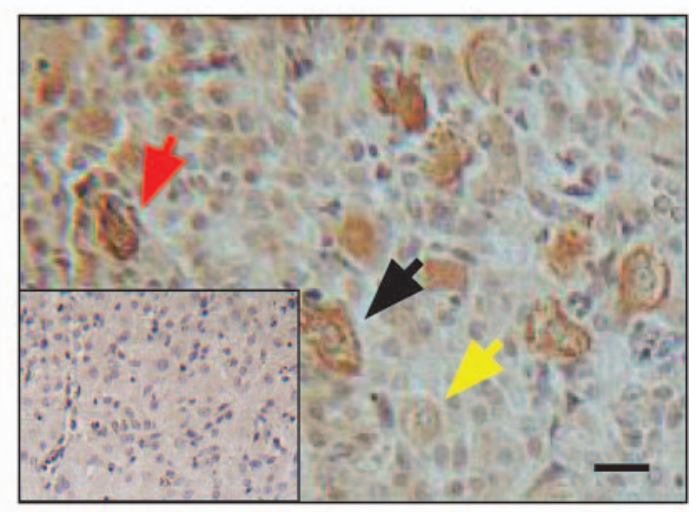

(D) Reg (TNF-RI)

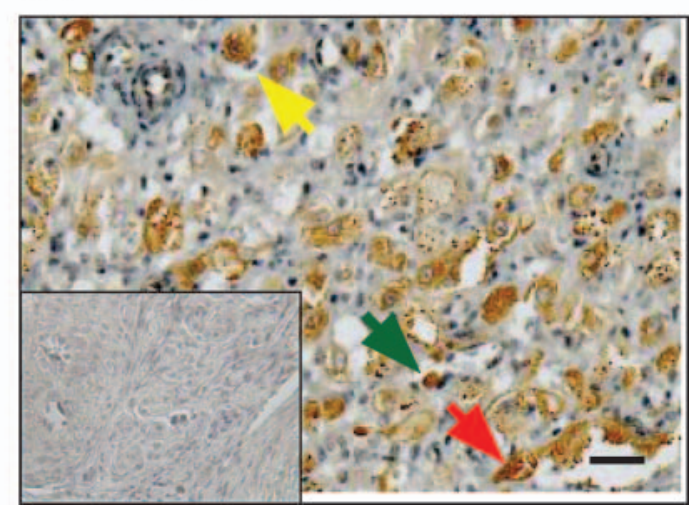

Figure 4. Representative images of immunohistochemical staining for tumor necrosis factor receptor (TNF-R) I in the bovine corpus luteum (CL) during the estrous cycle [early, A; mid, B; late, C; and regressed (Reg), D]. Large cells (black arrows), small cells [white (yellow) arrows], immune cells [dark gray (blue) arrows], and vascular endothelial cells [light gray (red) arrows] in the bovine CL showed positive immunoreactivity. No positive immunoreactivity was observed in negative controls (inset panels). Scale bars represent $25 \mu \mathrm{m}$. References to color refer to the color version available in the online PDF.

gressed stage in this study. This result is in agreement with a recent study in which TNF-RII mRNA was evaluated by semiquantitative PCR using another primer pair (Korzekwa et al., 2008). Unlike TNF-RI, TNF-RII lacks a cytoplasmic death domain, but it may have a role in regulating apoptosis through TNF-RI (Gupta, 2002). For example, TNF-RII was found to upregulate endogenous membrane-bound TNF production and to enhance TNF-RI-mediated apoptosis after autotropic and paratropic stimulation of TNF-RI (Grell et al., 1999). These findings suggest that TNF-RII may upregulate apoptotic signaling of TNF-RI in the bovine $\mathrm{CL}$ at the regressed stage.

Tumor necrosis factor- $\alpha$ is produced by immune cells of many species and by granulosa cells of cows (Roby and Terranova, 1989), pigs (Nakayama et al., 2003), rats (Roby and Terranova, 1989), and humans (Roby et al., 1990). In this study, positive immunologic staining for TNF- $\alpha$ was observed in several cell types in the bovine CL. The positive cells of CD8 were also observed in the CL cells. Although these results did not correlate with each other, they may indirectly support the idea that some of the TNF- $\alpha$ positive cells observed in this study may be immune cells. Because the large luteal cells are derived from granulosa cells (Alila and Hansel,
1984), it was expected that bovine large luteal cells would express TNF- $\alpha$. In the present study, several cell types in the bovine CL expressed positive immunological staining for CYP450, suggesting that these cells are steroidogenic large and small luteal cells. These results support that both the large and small luteal cells may express TNF- $\alpha$, as well as TNF-RI and TNF-RII, suggesting that the TNF produced by these cells acts as an autocrine regulator of luteal cell function.

The bovine CL is known as a transient organ, and its formation is accompanied by intensive vascularization. Endothelial cells of bovine CL secrete various substances that regulate luteal cell function, including endothelin-1, PG, and monocyte chemoattractant protein-1 (Girsh et al., 1996; Okuda et al., 1999; Cavicchio et al., 2002). Several vasoactive and angiogenic factors that are produced in the bovine CL participate in interactions between the endothelial cells and steroidogenic luteal cells (Miyamoto et al., 2009), which suggests that TNF- $\alpha$ produced by luteal cells and immune cells affects endothelial cell function in the CL. In this study, immunoreactivities for TNF-RI and TNF-RII were observed in several cell types in the CL tissues. Some of these TNF-RI- and TNF-RII-positive cells may be vascular endothelial cells (Hojo et al., 2009), which suggests that 
(A) Early (TNF-RII)

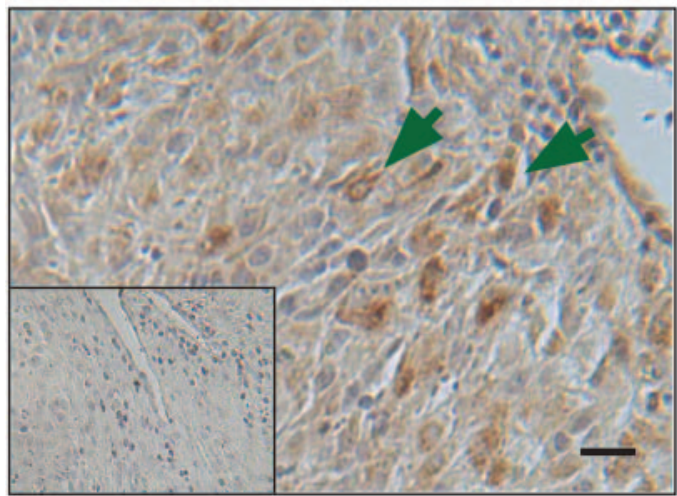

(C) Late (TNF-RII)

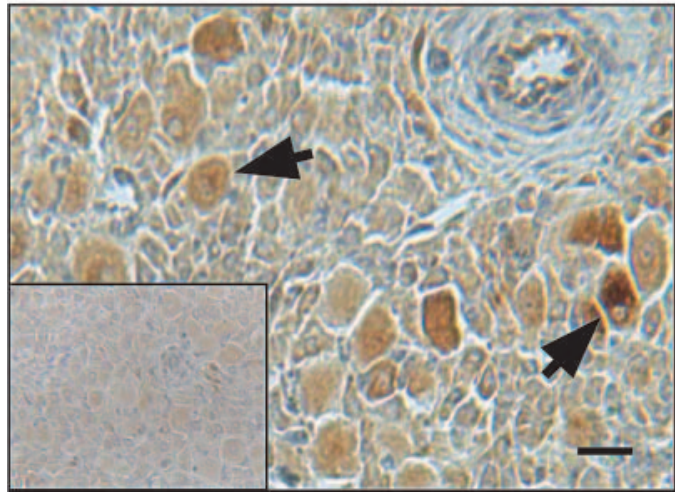

(B) Mid (TNF-RII)

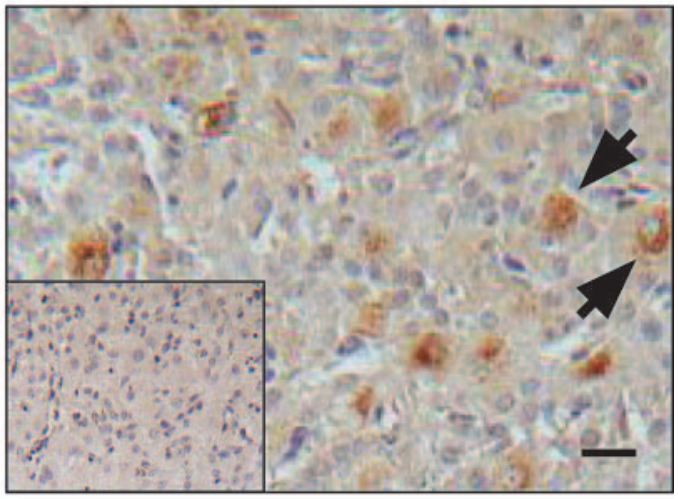

(D) Reg (TNF-RII)

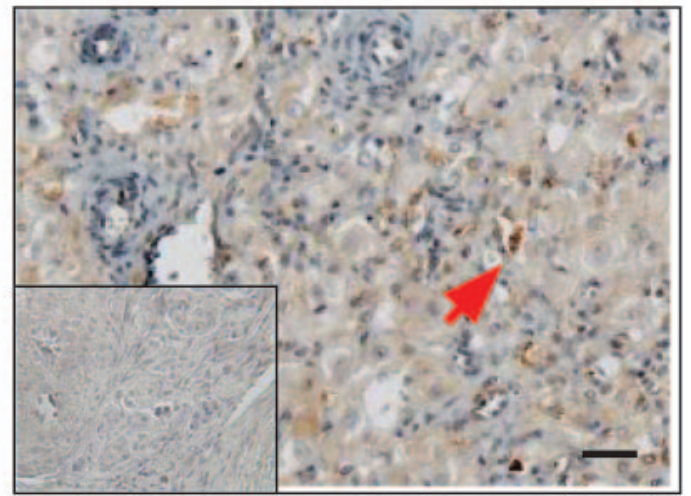

Figure 5. Representative images of immunohistochemical staining for tumor necrosis factor receptor (TNF-R) II in the bovine corpus luteum (CL) during the estrous cycle [early, A; mid, B; late, C; and regressed (Reg), D]. Large cells (black arrows), immune cells [gray (blue) arrows in (A)], and vascular endothelial cells [gray (red) arrow in (D)] in the bovine CL showed positive immunoreactivity. No positive immunoreactivity was observed in negative controls (inset panels). Scale bars represent $25 \mu \mathrm{m}$. References to color refer to the color version available in the online PDF.

TNF affects endothelial cell function, as well as luteal cell function in cows. It has been demonstrated that TNF- $\alpha$ induces cell death of cultured endothelial cells derived from bovine CL, and its action is mediated at least by TNF-RI (Pru et al., 2003). Apoptotic cell death of endothelial cells has been observed in bovine CL during structural luteolysis (Friedman et al., 2000). We recently demonstrated that the capillaries disappeared earlier than the large blood vessels during structural luteolysis in cows (Hojo et al., 2009). Together, these findings suggest that the increased TNF- $\alpha$ expression in bovine endothelial cells during luteolysis promotes the apoptosis of endothelial cells and the subsequent degeneration of capillaries in the CL.

In conclusion, this study suggests that TNF- $\alpha$ is present both in the large and small luteal cells, and in immune cells in bovine CL throughout the estrous cycle, and its concentration is greater at the regressed luteal stage than at the early, mid, and late stages. Both receptors of TNF- $\alpha$ may be present in not only the large and small luteal cells, but also the endothelial cells, and the abundance of TNF-RII mRNA is greatest in the regressed CL. These results suggest that TNF- $\alpha$ secreted by luteal and immune cells plays an autocrine or paracrine role in regulating luteal function through- out the estrous cycle in cattle via its specific receptors, TNF-RI and TNF-RII.

\section{LITERATURE CITED}

Abdo, M., S. Hisheh, F. Arfuso, and A. Dharmarajan. 2008. The expression of tumor necrosis factor-alpha, its receptors and steroidogenic acute regulatory protein during corpus luteum regression. Reprod. Biol. Endocrinol. 6:50.

Alila, H. W., and W. Hansel. 1984. Origin of different cell types in the bovine corpus luteum as characterized by specific monoclonal antibodies. Biol. Reprod. 31:1015-1025.

Arosh, J. A., J. Parent, P. Chapdelaine, J. Sirois, and M. A. Fortier. 2002. Expression of cyclooxygenases 1 and 2 and prostaglandin $\mathrm{E}$ synthase in bovine endometrial tissue during the estrous cycle. Biol. Reprod. 67:161-169.

Benyo, D. F., and J. L. Pate. 1992. Tumor necrosis factor- $\alpha$ alters bovine luteal cell synthetic capacity and viability. Endocrinology $130: 854-860$.

Carswell, E. A., L. J. Old, R. L. Kassel, S. Green, N. Fiore, and B. Williamson. 1975. An endotoxin-induced serum factor that causes necrosis of tumors. Proc. Natl. Acad. Sci. USA $72: 3666-3670$.

Cavicchio, V. A., J. K. Pru, B. S. Davis, J. S. Davis, B. R. Rueda, and D. H. Townson. 2002. Secretion of monocyte chemoattractant protein-1 by endothelial cells of the bovine corpus luteum: Regulation by cytokines but not prostaglandin $\mathrm{F}_{2 \alpha}$. Endocrinology 143:3582-3589. 
Friedman, A., S. Weiss, N. Levy, and R. Meidan. 2000. Role of tumor necrosis factor $\alpha$ and its type I receptor in luteal regression: Induction of programmed cell death in bovine corpus luteumderived endothelial cells. Biol. Reprod. 63:1905-1912.

Girsh, E., R. A. Milvae, W. Wang, and R. Meidan. 1996. Effect of endothelin-1 on bovine luteal cell function: Role in prostaglandin $\mathrm{F}_{2 \alpha}$-induced antisteroidogenic action. Endocrinology 137:1306-1312.

Grell, M., G. Zimmermann, E. Gottfried, C. M. Chen, U. Grunwald, D. C. Huang, Y. H. Wu Lee, H. Durkop, H. Englemann, and P. Scheurich. 1999. Induction of cell death by tumor necrosis factor (TNF) receptor 2, CD40, and CD30: A role of TNFR1 activation by endogenous membrane-anchored TNF. EMBO J. $18: 3034-3043$.

Gupta, S. 2002. A decision between life and death during TNF- $\alpha-$ induced signaling. J. Clin. Immunol. 22:185-194.

Hojo, T., M. O. Al-zi'abi, D. J. Skarzynski, T. J. Acosta, and K. Okuda. 2009. Changes in the vasculature of bovine corpus luteum during the estrous cycle and prostaglandin $\mathrm{F}_{2 \alpha}$-induced luteolysis. J. Reprod. Dev. 55:512-517.

Ihnatko, R., and M. Kubeš. 2007. TNF signaling: Early events and phosphorylation. Gen. Physiol. Biophys. 26:159-167.

Kenngott, R. A. M., and F. Sinowatz. 2008. Expression and distribution of intermediate-filament proteins and laminin during the development of the bovine Müllerian duct. Anat. Histol. Embryol. 37:223-230.

Korzekwa, A., S. Murakami, I. Wocławek-Potocka, M. M. Bah, K. Okuda, and D. J. Skarzynski. 2008. The influence of tumor necrosis factor $\alpha$ (TNF) on the secretory function of bovine corpus luteum: TNF and its receptors expression during the estrous cycle. Reprod. Biol. 8:245-262.

Miyamoto, A., K. Shirasuna, and K. Sasahara. 2009. Local regulation of corpus luteum development and regression in the cow: Impact of angiogenic and vasoactive factors. Domest. Anim. Endocrinol. 37:159-169.

Nakayama, M., N. Manabe, N. Inoue, T. Matsui, and H. Miyamoto. 2003. Changes in the expression of tumor necrosis factor (TNF) $\alpha$, TNFo receptor (TNFR) 2, and TNFR-associated factor 2 in granulosa cells during atresia in pig ovaries. Biol. Reprod. 68:530-535.

Niswender, G. D., J. L. Juengel, P. J. Silva, M. K. Rollyson, and E. W. McIntush. 2000. Mechanisms controlling the function and life span of the corpus luteum. Physiol. Rev. 80:1-29.

Okuda, K., S. Kito, N. Sumi, and K. Sato. 1988. Study of the central cavity in the bovine corpus luteum. Vet. Rec. 123:180-183.

Okuda, K., and R. Sakumoto. 2003. Multiple roles of TNF super family members in corpus luteum function. Reprod. Biol. Endocrinol. 1:95.

Okuda, K., R. Sakumoto, Y. Uenoyama, B. Berisha, A. Miyamoto, and D. Schams. 1999. Tumor necrosis factor $\alpha$ receptors in microvascular endothelial cells from bovine corpus luteum. Biol. Reprod. 61:1017-1022.

O'Shea, J. D., R. J. Rodgers, and M. J. D'Occhio. 1989. Cellular composition of the cyclic corpus luteum of the cow. J. Reprod. Fertil. 85:483-487.

Peluffo, M. C., K. A. Young, J. D. Hennebold, and R. L. Stouffer. 2009. Expression and regulation of tumor necrosis factor (TNF) and TNF-receptor family members in the macaque corpus luteum during the menstrual cycle. Mol. Reprod. Dev. 76:367-378.

Penny, L. A., D. Armstrong, T. A. Bramley, R. Webb, R. A. Collins, and E. D. Watson. 1999. Immune cells and cytokine production in the bovine corpus luteum throughout the oestrous cycle and after induced luteolysis. J. Reprod. Fertil. 115:87-96.

Pru, J. K., M. P. Lynch, J. S. Davis, and B. R. Rueda. 2003. Signaling mechanisms in tumor necrosis factor alpha-induced death of microvascular endothelial cells of the corpus luteum. Reprod. Biol. Endocrinol. 1:17.

Roby, K. F., and P. F. Terranova. 1989. Localization of tumor necrosis factor (TNF) in the rat and bovine ovary using immunohistochemistry and cell blot: Evidence for granulosa production. Page 273-278 in Growth Factors and the Ovary. A. N. Hirshfield, ed. Plenum Publishing Corp., New York, NY.

Roby, K. F., J. Weed, R. Lyles, and P. F. Terranova. 1990. Immunological evidence for a human ovarian tumor necrosis factor- $\alpha$. J. Clin. Endocrinol. Metab. 71:1096-1102.

Sakumoto, R., B. Berisha, N. Kawate, D. Schams, and K. Okuda. 2000. Tumor necrosis factor- $\alpha$ and its receptor in bovine corpus luteum throughout the estrous cycle. Biol. Reprod. 62:192199.

Sakumoto, R., T. Komatsu, E. Kasuya, T. Saito, and K. Okuda. 2006. Expression of mRNAs for interleukin-4, interleukin- 6 and their receptors in porcine corpus luteum during the estrous cycle. Domest. Anim. Endocrinol. 31:246-257.

Sakumoto, R., M. Vermehren, R. A. Kenngott, K. Okuda, and F. Sinowatz. 2010. Changes in the levels of progesterone receptor mRNA and protein in the bovine corpus luteum during the estrous cycle. J. Reprod. Dev. 56:219-222.

Shaw, D. W., and J. H. Britt. 1995. Concentrations of tumor necrosis factor $\alpha$ and progesterone within the bovine corpus luteum sampled by continuous-flow microdialysis during luteolysis. Biol. Reprod. 53:847-854.

Sinowatz, F., D. Schams, F. Habermann, B. Berisha, and M. Vermehren. 2006. Localization of fibroblast growth factor I (acid fibroblast growth factor) and its mRNA in the bovine mammary gland during mammogenesis, lactation and involution. Anat. Histol. Embryol. 35:202-207.

Skarzynski, D. J., M. M. Bah, K. M. Deptula, I. Wocławek-Potocka, A. Korzekwa, M. Shibaya, W. Pilawski, and K. Okuda. 2003. Roles of tumor necrosis factor of the estrous cycle in cattle: An in vivo study. Biol. Reprod. 69:1907-1913.

Skarzynski, D. J., K. K. Piotrowska, M. M. Bah, A. Korzekwa, I. Wocławek-Potocka, K. Sawai, and K. Okuda. 2009. Effects of exogenous tumour necrosis factor- $\alpha$ on the secretory function of the bovine reproductive tract depend on tumour necrosis factor- $\alpha$ concentrations. Reprod. Domest. Anim. 44:371-379.

Taniguchi, H., Y. Yokomizo, and K. Okuda. 2002. Fas/Fas ligand mediates luteal cell death in bovine corpus luteum. Biol. Reprod. 66:754-759.

Tartaglia, L. A., and D. V. Goeddel. 1992. Two TNF receptors. Immunol. Today 13:151-153.

Townson, D. H., C. L. O'Connor, and J. K. Pru. 2002. Expression of monocyte chemoattractant protein-1 and distribution of immune cell populations in the bovine corpus luteum throughout the estrous cycle. Biol. Reprod. 66:361-366. 